\title{
Predicament of Relationships in Jhumpa's Interpreter of Maladies
}

\author{
Dr. Abdul Wahab Siddiqui \\ Asst. Professor \& HoD \\ Department of English, MAJ University, Rampur UP (India) \\ E-mail: abdulwahabsiddiqui@gmail.com
}

\begin{abstract}
:
Jhumpa Lahiri published his short stories' collection 'The Interpreter of Maladies' The title of book is itself appears as a story. The story describes Das family and their tour experience in India. The development of people without understanding the root of real cultures of two countries makes irritable. People can migrate in other country and can adopt its culture but they cannot change their DNA from where they have come. Das family also faces the same problem. Their children were born in America and they have American culture and the result is that they have no control over children. Mrs Das cannot understand Mr Das and in the same way Mr Das can also not understand his wife. Mr Das has also no control over Children. Mr Kapasi is living a separate life even he has his wife. He is hired by Mr Das to see the Sun Temple. Everybody is living separate life in this short story. Nobody is satisfied with anybody. Married lives are dispersed. Mr Das and Mrs Das, Mr Kapasi and Mrs Kapasi are facing same problems in this short story. Mr Kapasi is an interpreter for a doctor who is unable to understand Gujarati patients because they speak in Gujarati so the doctor cannot understand them so Mr Kapasi helps the doctor to understand the patients' language. Mr Kapasi becomes interpreter between doctor and patients.
\end{abstract}

Keywords: Relation-Conflict, Migration, cultural difference, dislocation

\section{Introduction}

They are living a full family life yet, Mrs. and Mr Das's children are totally unaware with the situation at home and in family. They are busy in their life by ignoring their parents. They are the symbol of American culture and its development. They are practical children because they think for themselves only. Mrs Das is also practical in nature. She is happy to live what she likes to do. Living in a family but living separate life is considered ideal for them. Such things make unaware to one another. Happy situation is not happy always. American lifestyle has been followed by the children as well as Mrs Das also. Das family seems to be united 
seemingly but they are not actually. Mrs Das has hidden affair which is known by her only. Her son Bobby is not Mr Das's son. Bobby was the son of her husband's friend with whom she had affair. Nobody is aware of this fact except Mrs Das herself. Bobby's appearances physically and mentally do not fit to Mr Das though nobody doubt on Mrs Das. Whole family is living as if they were living a zoo life. Modernity has taken over them so far as if they were alien. Family is not just to see one another but to feel one another is heart of understanding. Only so called relations are there remained in Das family so they are unaware of one another. Intimacy is no more now in their relations. Closeness among them is closed.

The door of life style is opened but everyone is living so called fashionable life. Mr Kapasi is also facing same problem with his wife. His wife is also unhappy with him though he is an interpreter for the doctor. Mrs Das's relation with Mr Das's one of the friends is result of unhappiness with her husband. It is out of morality that a wife engaged in extramarital relation. It cannot be said that it is a kind of modernity. Modern development has caused many problems in the matter of morality. Extra-marital relation is one of them. Mrs Das does not believe that she has done anything wrong. It is the modern society where it is found common thing so she does not feel anything hurt. She tells this hidden secret to Mr Kapasi thinking he is interpreter and he can interpret it well. He is expected a good interpreter on behalf of her. Modern society is satisfied with psychological understanding that reveals mental made positive correctness.

It can be seen in Mrs Das's extra-marital relationship. The question arises in the mind of readers whether she has fallen in love with her husband's friend or just wants to enjoy her life because she is not satisfied with her husband. She takes such a step that can harm her whole life yet she is not afraid of it. Liberty is not out of morality. If it is considered on the basis of morality, it cannot be considered moral act. Modernization does not allow such things to be happen in the relationship between husband and wife. She is unaware of coming days in future. The second question arises in the reader's mind whether she has not thought about her future. She is also unaware of this truth telling incident may lose respect of Mr Kapasi who is just a guide for a while in India.

\section{A home of cultural conflicts:}


Mrs Das is living in America now but she is having culture of India. It may happen that one can go and develop fully in other country but culture leaves its impact on one's life. One can leave ones country easily but cannot leave ones culture easily as Mrs Das and her family. Children were brought up in America so they have accepted its culture fully. They cannot feel even any wrong thing in the matter of respect their elders. They don't find anything is wrong in this matter that they do not respect their parents. Even they do not bother of it. They think that it is their liberty. There is a line drawn by two different cultures. It is very difficult to follow one's own culture living in other's country whether living permanently or temporary. Indian culture has its own boundary that one is not allowed to harm anyone with greed and money or for the name of development. Unhappy marriages are tolerated by Indian couples even if they cannot bear each other. American culture is different in the matter of such things. Mrs Das is caught in the middle of these two cultures. One thing is clear that Mr Kapasi and Mrs Das both are dissatisfied with their married life but both of them cannot break the relationship. Mr Kapasi is not happy with her wife and Mrs Das is not happy with her husband. Mr Kapasi starts taking interest in Mrs Das while she took interest in her husband's friend. Mr Kapasi is interpreter but unable to interpret the problem of his wife and as well as Mrs Das. Mrs Das opens her secret that she has relationship with her husband's wife thinking that it must be interpreted by Mr Kapasi so well but she is shocked seeing Mr Kapasi thinking her characterless. Mr Kapasi's wife also wants to be interpreted her son's death but she is also shocked and she starts living separately. Two different cultures make the lives of them difficult. Mr Das wants sympathy from the side of Mr Das after telling the truth but she is shocked. Mr Kapasi also wants sympathy from the side of Mrs Das but he is also shocked hearing her hidden truth. Two different cultures never make them united heartily because they expected far from their cultures. One culture makes it fair the other culture makes it unfair. Children are happy because of foreign culture but others are unhappy. Even after coming in India they find no happiness. Children are getting bore and parents are taking no interest each other. Mrs Das has to suffer maladjustment of two different cultures. Children, Mr Das, Mrs Das all of them have to suffer mal adjustment of two different cultures.

\section{Conclusion:}

Such two different cultures have created havoc in the life of Mr and Mrs Das. The family 
Journal of Advance Research in Science and Social Science (JARSSC)

Official Publication of Indian Mental Health \& Research Centre

DOI: $10.46523 /$ jarssc.04.02.01

Multidisciplinary, Open Access
ISSN: 2582-2004

Volume 04, Issue 02

living in other countries must be facing problems. Belief and culture is two facet of human life. If one fails to do balance of two different cultures in their life, they will remain nowhere. One can find meaning of words according to their belief and culture. Mrs Das has to leave the place where she tells frankly her hidden secret of extra-marital relationship but she gets hurt instead of being interpreted positively. Kapasi cannot understand her. He can interpret language but cannot interpret feeling. It is proved by his thinking that he starts thinking her characterless. He is successful in interpreting language for the doctor. Sin and virtue both are born by the same mother but it depends on understanding. It takes its birth from the culture of country. Writer has beautifully described the two different cultures in well manner and clears her objective simultaneously.

\section{REFERENCES}

Lahiri, Jhumpa. Interpreter of Maladies.USA: Mariner Books, 1999.

SparkNote Editors.’SparNotes on Interpreter of Maladies.’SparkNote.com. SparkNote LLC, 2007.Web.18Apr.2019.

Karim, Rezaul: Jhumpa Lahiri: South Asian Writers in English.Ed.Fakrul Alam.Farmington Hills, MI: Thomson Gale, 2006.

Nityanandam Indira: Jhumpa Lahiri: The Tale 